How to cite this article:

Tingting, X., \& Yong, W. (2020). The stock market's reaction to strict environmental inspection: Evidence from heavily polluting listed companies in China. International Journal of Banking and Finance, 15(2), 95-117. https:// doi.org/10.32890/ijbf2020.15.2.5

\title{
The Stock Market's Reaction to Strict Environmental Inspection: Evidence from Heavily Polluting Listed Companies in China
}

\author{
${ }^{1}$ Xie Tingting \\ Peking University School of Economics, Beijing, China \\ Wang Yong \\ Policy Research Center for Environment and Economy, Ministry \\ of Ecology and Environment, Beijing China ${ }^{1}$ Corresponding \\ author: xietingting19@pku.edu.cn; \\ wangyong1228@163.com
}

A R T I C L E I N F O

Article history:

Received 28 February 2020

Revised 22 June 2020

Accepted 29 June 2020

Published 31 July 2020

JEL Code: G38, Q58

Keywords:

Central environmental inspection, event study, stock market, China
A B S T R A C T

As an important part of the new environmental governance system in China, the policy effect of Central Environmental Inspection has gained more attention. Based on the data from heavily polluting listed companies in China, this paper examines the impact of Central Environmental Inspection on corporate value by using an event study approach. The result of the study demonstrates that the Central Environmental Inspection causes a general and significant negative impact on the corporate value of heavily polluting listed companies. More specifically, the market value of private firms and small-scale firms declined more than that of state-owned firms and big-scale firms. In addition, under the deterrent of the Central Environmental Inspection, political connections have no longer become the effective way for polluting firms to evade strict environmental regulation. 


\section{Introduction}

In the space of a few years, China's efforts to protect ecological environment have been greatly enhanced. Taking the improvement of air quality as an example, the average concentration of $\mathrm{PM}_{10}$ in 338 prefecture-level cities had decreased by 22.7 percent in 2017 compared with 2013. While the average concentration of $\mathrm{PM}_{2.5}$ in Beijing-Tianjin-Hebei region, Yangtze River Delta and Pearl River Delta decreased by 39.6 percent, 34.3 and 27.7 percent respectively. During the same period, the new environmental governance system was gradually taking shape in China. As the core institutional arrangement of environmental governance framework in the new era, the Central Environmental Inspection which was implemented in 2016 directly promoted resolving a large number of long-standing environmental problems. And then it was defined as the regular function of the Ministry of Ecology and Environment established in 2018 which means that it will play a more important role in China's environmental protection.

The fundamental purpose of Central Environmental Inspection is to urge local governments to fulfill the responsibility of handling the environmental protection seriously and to promote the internalisation of environmental cost of polluting enterprises fully. From the perspective of financial market, the corporate environmental performance would become an important factor affecting investors' decision-making under the strong promotion of central supervision. That is to say, if investors can respond positively to the environmental inspection of central government and then change their investment behaviours correspondingly to make a punitive reaction to the heavily polluting enterprises, it can be proved that Central Environmental Inspection is really an effective policy that can drive the green transformation of enterprises through the path of financial market. The experiences of pollution control in United States and Europe Union both showed that the feedback of financial market on environmental policies, such as environment law enforcement and information disclosure, was the successful way to promote the internalisation of environmental cost.

There are two types of literature focusing on the effect of environmental policies from the field of financial market. The first is to test the investors' reaction to the environmental information disclosure. Based on the US stock market, Badrinath and Bolster (1996) found that companies suffered an average market value loss of 0.43 percent after the disclosure of environmental penalty information. Konar and Cohen (1997) also believed that the environmental information disclosure was an effective mechanism to reduce pollution emission of polluting enterprises. When the environmental penalty information was released, companies who suffered a larger loss of market value reduced more pollution emission than other companies in the same industry. Foulon et al.'s 
study (2002) showed that the environmental information disclosure was better in improving the corporate environmental performance than the traditional legal regulation in Canada. Based on European and Indian respectively, Lundgren and Olsson (2010), and Gupta and Goldar (2002) also found a similar mechanism on the impact of environmental disclosure policies on financial markets. However, most of the studies in China indicated that the response to environmental illegal information disclosure was weak in A-share market. In the study by $\mathrm{Xu}$ et al. (2012), the environmental illegal information published by the Ministry of Environmental Protection had no significant impact on the stock price of listed companies. Wang and Li (2013) found that A-share market had no significant punitive response to the environmental accidents and negative information that had not passed the environmental audit. Using the case of pollution incident of Zijin Mining, Shen et al. (2012) found that the response of A-share market to major environmental pollution accidents was weaker than that of the H-share market and A-share market cannot respond effectively to government penalties and environmental litigation. Fang and Guo (2018) believed that lower environmental violation cost was the fundamental reason for the failure of China's environmental information disclosure policy because local governments preferred to relax environmental regulation to protect local economic growth and impose soft constraints on local enterprises. The second is the impact of macro environmental policies on the capital market. By using the event study method, Ramiah et al. (2013) examined the impact of 19 environmental regulation policies on the stock market in Australia from 2005 to 2011 and found that the Australian stock market was most sensitive to the release of the Carbon Pollution Reduction Scheme. Zhang and Zhang (2017) evaluated the impact of the promulgation and implementation of China's new Environmental Protection Law on listed companies in heavy-polluted industries and found that the new law caused significant negative stock price shocks.

From the literature review, the existing researches were mainly focused on examining the response of the financial market to corporate environmental information disclosure but less on the impact of macro-environmental policies on capital market. Theye still lack in-depth empirical test of Central Environmental Inspection which is not compatible with the actual progresses in China. Taking the first round of Central Environmental Inspection as the research object, we empirically examine the short-term impact of Central Environmental Inspection on the corporate value of polluting listed companies using the event study method and the types of companies that are more sensitive to environmental inspection. The study shows that the implementation of Central Environmental Inspection brings obvious negative shock effect on the corporate value of heavily polluted listed companies. And the negative impact becomes more and more significant with the increasing disclosure of Central Environmental Inspection in various 
media. Besides, the negative impact of Central Environmental Inspection appears to be more significant in private enterprises and relatively small enterprises. And under the deterrence of central supervision, political connection is no longer an effective way for enterprises to evade environmental regulation and the spillover effect appears in non-inspected provinces.

The contribution of this study is mainly reflected in the following two aspects. Firstly, existing literatures are mainly focusing on testing the impact of environmental law and regulation, environmental information disclosure and other relevant policies, but little research has been done on the impact of the recent implementation of the new environmental management system in China, lacking necessary evaluation of the effectiveness of Central Environmental Inspection. Therefore, this study complemented the existing literatures. Secondly, the possible influencing mechanisms on capital market are combed and heterogeneous response of different listed companies is examined in this paper, which with a view of make a useful supplement to the relevant research.

The remainder of this paper is structured as follows. The second section, the presents the institutional background and influencing mechanisms of the Central Environmental Inspection. Section three describes the research method and data source which were used in this study. Section four presents the empirical results. Meanwhile, Section five reveals the results of heterogeneous effect. Finally, section six concludes with a discussion on the outputs of the study.

\section{Institutional Background and Influencing Mechanisms}

\subsection{Institutional Background}

Weak enforcement was always regarded as a major factor affecting the effectiveness of environmental policy efforts in China. One part of this problem is that most works are carried out by local governments under China's decentralised system of environmental governance. However, local governments are often more concerned with the economic growth rather than environmental protection. Therefore, there is a strong incentive for the local governments who are the environmental policy executors to ignore the environmental violations for the sake of getting more fiscal revenue. Although the new Environmental Protection Law is called "the strictest environmental law" in recent Chinese history after it was issued in 2015, its validity is still being questioned to some extent.

The working arrangement of Central Environmental Inspection was set up by China's central government for the purpose of monitoring the local implementation of environmental laws and policies from 2016 which is an 
important institutional innovation in the field of ecological civilisation system reform. In the last two years, the first round of inspection saw investigations conducted in 31 provinces and that had successfully solved more than 80,000 environmental problems. Specifically, the first round of inspection received more than 135,000 complaints from the public in which it handled 29,000 cases and issued fines totaling 1.43 billion Yuan. Approximately, 18,448 officials were investigated and 18,199 were found responsible for some cases.

In the name of the CPC Central Committee and the State Council, central inspection was endowed with the higher authority and rigidity, emphasising the same responsibilities of CPC committees and governments at all levels in environmental protection. Through the implementation of inspection, the targets of environmental supervision are shifted from sole enterprises to both Local party committees and governments, making environmental supervision more deterrent than before. In the process of inspection, environmental supervision mainly targets provincial party committees, governments and their relevant departments and can directly sink into municipal party committees and governments or conduct in-depth investigation on some related enterprises if necessary.

As shown in table 1, the specific situation of the first round of Central Environmental Inspection was sorted out. On January 4, 2016, the first inspection group was stationed in Hebei Province to carry out the pilot work of supervision. After the pilot project, the Central Environmental Inspection carried out four batches of supervision work in 2016 and 2017, covering the remaining 30 provinces. According to the work plan of environmental inspection, each batch of inspection lasts for about one month and involves seven or eight provinces in general. The whole inspection process was divided into three stages, each of which lasts for about 10 days. The first stage was to talk with the leaders of provincial CPC committees, governments and related departments to consult them on the relevant materials on local environmental protection work, to visit relevant departments and at the same time to receive the public complaints. The second stage was to conduct an investigation and verification aiming at the problems and clues sorted out during the first period. The purpose of this stage was to assess the seriousness of the problems and implement the allocation of responsibilities. The third stage was to summarize basic conclusions of inspection, present reporting framework and carry out targeted supplementary supervision. And then, about three months later, each environmental inspection group would provide feedback on the inspection results and corrective suggestions on supervised provinces which mainly include problems discovered and penalty opinions. 
Table 1. Implementation of the First Round of Central Environmental Inspection

\begin{tabular}{|c|c|c|c|}
\hline Batches & Period & Coverd region & Punishment results \\
\hline $\begin{array}{c}\text { Pilot } \\
\text { project }\end{array}$ & 2016.01.04-2016.02.04 & Hebei & $\begin{array}{l}2856 \text { cases were ordered } \\
\text { to be rectified, } 123 \text { persons } \\
\text { were detained; } 65 \text { persons } \\
\text { were inquired, } \\
366 \text { persons were held } \\
\text { accountable. }\end{array}$ \\
\hline $\begin{array}{l}\text { First } \\
\text { batch }\end{array}$ & 2016.07.12-2016.08.19 & $\begin{array}{l}\text { Inner Mongolia, } \\
\text { Heilongjiang, } \\
\text { Jiangsu, Jiangsu, } \\
\text { Henan, Guangxi, } \\
\text { Yunnan, Ningxia }\end{array}$ & $\begin{array}{l}9617 \text { cases were ordered to } \\
\text { be rectified, } 2659 \text { cases were } \\
\text { put on record and punished, } \\
310 \text { persons were detained; } \\
2176 \text { persons were inquired, } \\
3287 \text { persons were held } \\
\text { accountable. }\end{array}$ \\
\hline $\begin{array}{l}\text { Second } \\
\text { batch }\end{array}$ & 2016.11.24-2016.12.30 & $\begin{array}{l}\text { Beijing, Shanghai, } \\
\text { Hubei, Guangdong, } \\
\text { Chongqing, } \\
\text { Shaanxi and Gansu }\end{array}$ & $\begin{array}{l}15631 \text { cases were ordered } \\
\text { to be rectified, } 6310 \text { cases } \\
\text { were put on record and } \\
\text { punished, } 265 \text { persons were } \\
\text { detained, } 4666 \text { persons were } \\
\text { inquired, } 3121 \text { persons were } \\
\text { held accountable. }\end{array}$ \\
\hline $\begin{array}{l}\text { Third } \\
\text { batch }\end{array}$ & 2017.04.24-2017.05.28 & $\begin{array}{l}\text { Tianjin, Shanxi, } \\
\text { Liaoning, Anhui, } \\
\text { Fujian, Hunan and } \\
\text { Guizhou }\end{array}$ & $\begin{array}{l}20359 \text { cases were ordered } \\
\text { to be rectified, } 8687 \text { cases } \\
\text { were put on record and } \\
\text { punished, } 405 \text { persons were } \\
\text { detained, } 6657 \text { persons were } \\
\text { inquired, } 4660 \text { persons were } \\
\text { held accountable. }\end{array}$ \\
\hline $\begin{array}{l}\text { Fourth } \\
\text { batch }\end{array}$ & 2017.08.07-2017.09.15 & $\begin{array}{l}\text { Jilin, Zhejiang, } \\
\text { Shandong, Hainan, } \\
\text { Sichuan, Tibet, } \\
\text { Qinghai and } \\
\text { Xinjiang }\end{array}$ & $\begin{array}{l}32602 \text { cases were ordered } \\
\text { to be rectified, } 10806 \text { cases } \\
\text { were put on record and } \\
\text { punished, } 424 \text { persons were } \\
\text { detained, } 4855 \text { persons were } \\
\text { inquired, } 6471 \text { persons were } \\
\text { held accountable. }\end{array}$ \\
\hline
\end{tabular}

\subsection{Influencing Mechanisms}

\subsubsection{Information transmission}

As a highly authoritative body, the Central Environmental Inspection can transmit more apparent signals for the determination of central government to strengthen environmental governance which will make investors to begin paying more attention to the environmental performance of listed companies. Naturally, compared with other companies, the heavily-polluted enterprises will become 
the risk aversion object for the potential investors. And although the main purpose of environmental supervision is to urge local governments to fulfil the environmental protection responsibility, its effect will eventually be transmitted to the production process of enterprises and greatly increase the environmental costs. Under strict environmental supervision, enterprises need to reallocate part of theinvestment to pollution control, which will crowd out productive investment and lead to a decline in output to some extent. Therefore, a sudden increase in the environmental cost caused by the Central Environmental Inspection and its possible effect on corporate performance will become an important factor for investors to consider. In the short run, the central environmental supervision will undoubtedly send adverse news to the capital market and very likely trigger a negative reaction from the capital market, especially for polluting industries. Besides, if the accurate information about some polluting companies can be transmitted effectively through the Central Environmental Inspection, the negative reaction of the market value will be strengthened according to the different environmental cost borne by different enterprises.

\subsubsection{Deterrent effect}

Under the powerful implementation of Central Environmental Inspection, pollution behaviours of all kinds of enterprises and in particular, the local officials who did not act will be punished seriously. Hence, for the local governments and polluters, the inspection action itself has a shocking effect. More critically, the local political connections, as an important competitive advantage of polluting enterprises, will be broken to an extent by the strict environmental supervision. The essence of the relationship between government and enterprise is the game between the administrative power and market power, of which political connection is the key factor. Under the government-led economic development, some policy risks can be avoided through the political connection between enterprises and government. Maung et al. (2015) found that state-owned enterprises have lower environmental taxes due to certain political connections. That is to say, political connections actually affect the implementation of local environmental policies. In fact, the main purpose of the Central Environmental Inspection is to weaken the political connection between local governments and polluting enterprises and promote the implementation of the environmental regulation policies.

\subsubsection{Resource reallocation}

From the existing empirical results, the impact of pollution control on production performance shows obvious heterogeneity according to the different characteristics of enterprises. Compared with other enterprises, listed companies have a better 
performance in environmental information disclosure and environmental social responsibility. Therefore, when facing central environmental supervision, listed companies may be less stressed than non-listed companies. . Scattered, messy and highly polluting businesses are the main targets of the central environmental supervision. Therefore, small companies in heavily polluting industries are usually under greater pressure, and more likely to reduce production or even be shut down. To a certain extent, due to the short-term crowding-out effect of environmental inspection on the output of SMEs, listed companies will be more competitive in the market because of their better environmental advantages. From this point of view, the central environmental supervision will bring about the reallocation of resources in the capital market.

\section{Research Methodology}

\subsection{Method}

We employed an event study approach to examine the reactions of the stock market to the central environmental inspection. Event study method is widely used in relevant literature. The basic idea is to make sure whether there are significant abnormal returns of relevant listed companies before and after the occurrence of an event date.

\subsubsection{Event date}

To implement an event study, we first needed to identify a clear event date. According to the supervision process, each batch of the Central Environmental Inspection involved two important dates; one was the date when the supervision groups were stationed, the other was the date when the supervision group provided feedback on specific opinions to the local goverment and also to the public synchronously. The latter reflects the inspected problems and corresponding processing results, such as the officials held accountable and the amount of the fine, which may have a direct deterrent effect.

Before the first batch of Central Environmental Inspection, a pilot project was carried out in Hebei province. But from the perspective of media exposure, public attention is relatively lower. In addition, as the central environmental inspection was a newly proposed mechanism, the specific impact on economy and enterprises may still be unknown to investors. After the pilot study period, investors may develop a certain understanding of the central environmental inspection. Therefore, the first large-scale central environmental inspection may have a more significant impact on the stock market. For the second one, during the period of the third and fourth batch of central environmental inspection, 
investors may already have obvious expectations after experiencing the first inspection. And also, the days of the inspection teams' arrival are close to the feedback days of the previous batch which make it difficult to identify the effective impact of the event.

Because the first batch of central environmental inspection involved seven provinces, the dates of entry of each inspection group were different, though the dates were close. The date range of stationing was from July 12 to July 19, 2016 and the date range of feedback was from November 14 to November 23, 2016. The keyword search trend and information exposure were provided by the 360 search index (Fig.1) The 360 search is a search engine which is commonly used in China as it can draw the public attention to the central environmental supervision events. In terms of trend index, the focus of the keywords of central environmental inspection and environmental inspection increased sharply on July 14, 2016 and July 15,2016 , respectively. In terms of exposure, the two keywords rose sharply on July 15 . In the following month, there was still a continuous concern trend of central environmental supervision. But in September and October, after the end of the first batch of central environmental inspection, the public concern on the incident declined dramatically. Until November 14, the inspection groups started to send feedback opinions to the inspected provinces and the public attention increased sharply again. Thus, we used both the supervision groups station (July 12) and the supervision group feedback (November 14) in the first batch of central environmental supervision as the event dates.

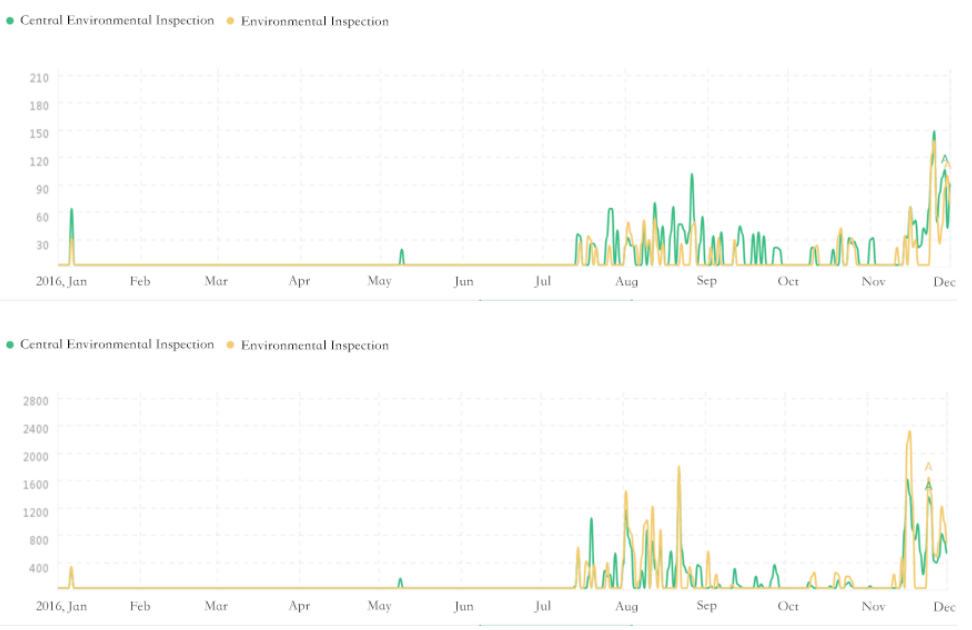

Figure 1. Trends in Concern (above) and Exposure (below) of Central Environmental Inspection 


\subsubsection{Event window}

Event study requires the occurrence of events to be unpredictable. However, sometimes it is difficult to ensure that information is not disclosed in advance. And also, the station and feedback process of the inspection was gradual which would cause the attention of media and the public be lagged behind. From figure 1 , it can be seen that the attention on environmental inspection was gradually increasing. Therefore, according to the existing relevant research, four time windows $[-5,5],[-5,10],[-10,10],[-10,20]$ are set to test the reaction of the stock market.

\subsubsection{Estimation window and calculation of CAR}

For the existing research, we take 120 days before the event day as the estimation window to avoid the possible impact of the event itself on the normal rate of return. CAPM model is used to estimate the normal return rate.

$$
R_{i t}=R_{f t}+\alpha_{i}+\beta_{i}\left(R_{m t}-R_{f t}\right)+\mu_{i t}
$$

Where $R_{i t}$ is the daily rate of return of stock $\mathrm{i}$ on day $\mathrm{t} ; R_{m t}$ is the average rate of return in Chinese stock market; $R_{f t}$ is the daily risk-free rate of return, which is usually assumed to be zero. $R_{i t}$ and $R_{m t}$, represented by the daily stock return rate of cash reinvestment and the comprehensive market return rate of cash reinvestment (the weighted average method of circulation market value) respectively, are selected from CSMAR database. And $\varepsilon_{i t}$ is the error term.

The abnormal return $\left(A R_{i t}\right)$ and cumulative abnormal return $\left(C A R_{i t}\right)$ are calculated respectively as below:

$$
\begin{aligned}
& A R_{i t}=R_{i t}-\hat{\alpha}_{i}-\hat{\beta}_{i} R_{m t} \\
& C A R_{i t}\left(t_{1}, t_{2}\right)=\sum_{t=t_{1}}^{t=t_{2}}\left(R_{i t}-\hat{\alpha}_{i}-\hat{\beta}_{i} R_{m t}\right)
\end{aligned}
$$

Where $\hat{\alpha}_{i}$ and $\hat{\beta}_{i}$ are the constant term and regression coefficient of OLS estimation in the event estimation window; $\operatorname{CAR}_{i t}\left(t_{1}, t_{2}\right)$ is the cumulative abnormal return of listed company $i$ in the event window $\left(t_{1}, t_{2}\right)$.

\subsection{Heterogeneity of Market Response}

To examine the heterogeneous reaction to the event, we further calculated the CAR by dividing the listed companies into different groups according to the enterprise characteristics and tested the significance of the difference. Specifically, we considered the following grouping characteristics. 


\subsubsection{Firm ownership}

There are great difference between state-owned enterprises and private enterprises in China. The differences are mainly manifested in the following aspects. The first is financing capacity. Private enterprises usually face greater financing constraints. The second is political ties. State-owned enterprises are controlled by the governments. The natural political connections make the local governments likely show paternalism toward the state-owned enterprises and tend to relax the environmental regulation on the state-owned enterprises. The third is social responsibility. Unlike the private enterprises, the state-owned enterprises not only pursue profits but also have a non-profit social function which determines that the state-owned enterprises need to take both economic and social responsibilities. In addition, the leaders of state-owned enterprises usually have administrative positions that may even be higher than the positions of the officials of local environmental protection departments. Therefore, in the face of environmental regulation, the state-owned enterprises have stronger ability to resist. On the other hand, when the environmental protection becomes a national will, in order to meet the requirements of central government, the stateowned enterprises will have to show their nature of quasi-government to assume more social responsibility and improve the environmental behaviours. In this way, it can convey to the public the positive attitude toward the environmental protection and fulfil environmental responsibilities, alleviating the pressure from external public opinions. To examine the heterogeneous influence of central environmental supervision on state-owned and non-state-owned enterprises, we constructed variable $s_{i}$, which equals to one for state-owned enterprise, and zero otherwise, according to the ownership of listed companies in CSMAR database.

\subsubsection{Political connection}

Under the government-led economic development, some risks from the environmental regulation policies can be avoided by building the local political connections. Compared with the natural political connections of state-owned enterprises, the private enterprises are more initiative and active in building their political connections. Because political ties are helpful to relieve environmental policy pressure for enterprises, the disclosure quality of environmental information of private enterprises with high political ties is more sensitive to environmental regulations. So, the variable connect $_{i}$ is built to consider the heterogeneous influence of the central environmental inspection on the enterprises with different political affiliates. In this study, connect $_{i}$ is a dummy variable for political connections, which takes the value of one if a top management team member belongs to the governments and zero otherwise. 


\subsubsection{Firm size}

Because of the existence of scale economy, the emission reduction costs, especially the fixed costs, will be apportioned with the increase of enterprise scale, such as sales volume and lead to the decline of the long-term average cost curve. Therefore, the relative emission reduction cost of large enterprises will be smaller. Compared with the large-scale enterprises, the rising environmental costs will bring greater burden to small-scale enterprises, making the survival of small-scale enterprises more difficult. Also, under the environmental regulation, the dominant position of large-scale enterprises will be further enhanced because of the increasing entry barriers. The inconsistency of raised environmental cost will bring different effect on enterprises of different sizes. We used the logarithm of the total assets of listed companies to reflect the firm size and examined the heterogeneity of the impact of central environmental supervision on different scale enterprises.

\subsection{Data Source}

The data of listed companies used in this paper are from the China Stock Market and Accounting Research Database (CSMAR). According to the Guidelines for Environmental Information Disclosure of Listed Companies issued by the Ministry of Environmental Protection, 19 industries are defined as heavily polluting industries. At last, corresponding to launch event and feedback event of Central Environmental Inspection, there are 790 and 814 listed companies in our research, which cover all polluting corporations listed on China's stock exchanges. Table 2 is the descriptive statistics of relevant variables.

Table 2. Summary Statistics of Relevant Variables

\begin{tabular}{llccccc}
\hline & Variable & Obs & Mean & Std. Dev. & Min & Max \\
\hline $\begin{array}{l}\text { Firm } \\
\text { characteristics }\end{array}$ & soe & 813 & 0.4108 & 0.4923 & 0 & 1 \\
& size & 813 & 22.3205 & 1.2768 & 18.6547 & 28.1788 \\
& connect & 813 & 0.2940 & 0.4559 & 0 & 1 \\
Launch event of & inspect & 814 & 0.2236 & 0.4169 & 0 & 1 \\
inspection & CAR(-5,5) & 792 & -0.0035 & 0.0693 & -0.3361 & 0.4019 \\
& CAR (-10,10) & 790 & -0.0195 & 0.1077 & -0.5548 & 0.5760 \\
& CAR (-10,20) & 790 & -0.0401 & 0.1348 & -0.6583 & 0.4543 \\
Feedback event & CAR(-5,5) & 811 & -0.0047 & 0.0735 & -0.2713 & 0.5144 \\
& CAR inspection $(-10,10)$ & 814 & -0.0242 & 0.0921 & -0.4796 & 0.4499 \\
& CAR (-10,20) & 811 & -0.0443 & 0.1186 & -0.5398 & 0.7937 \\
\hline
\end{tabular}




\section{Results}

\subsection{Market Responses}

To examine the market responses to the event, we first estimated a market model over a 120 estimation window ending 11days before the event date. A valueweighted average return of all stocks in our sample is adopted as the market return. We then calculated cumulative abnormal returns (CARs) over an 11 day $(-5,5)$ event window centred on the start date and feedback date of the inspection and tested their statistical significance respectively. To establish the robustness of our results, we also considered two longer event windows, a 21-day window and a 31-day window. As shown in Table 3, the average of the CARs is negative and significantly different from zero. And compared with the start-up day event, we can see a greater negative response of the stock market of the feedback event. According to the CARs in the event window of 11 days, the central environmental supervision results in a 0.35 and 0.47 percentage point decline of the market returns during the start-up and feedback event window respectively, but the results are not so significant. In the event window of 21 days, we can see a 1.95 and a 2.87 percentage point significant decline of market returns after the start date and feedback date of the supervision. The results show that with the increasing attention and exposure of the central environmental supervision, the impact on the market value of heavily polluted enterprises become more significant and persistent. Using a natural experiment generated by the National Specially Monitored Firms (NSMF) in China, Zhang et al. (2018) found that central supervision significantly reduced the emission intensity of industrial enterprises. These results highlight the substantial room for improvement in Chinese environmental regulations via central supervision.

Table 3. Stock Market Reactions

\begin{tabular}{ccc}
\hline \multirow{2}{*}{ Model } & \multicolumn{2}{c}{ Average CAR } \\
& Inspection Start & Inspection Feedback \\
\hline \multirow{2}{*}{ CAR $(-5,5)$} & -0.0035 & $-0.0047^{*}$ \\
& $(0.0025)$ & $(0.0026)$ \\
CAR $(-10,10)$ & $-0.0195^{* * *}$ & $-0.0287^{* * *}$ \\
& $(0.0038)$ & $(0.0018)$ \\
CAR $(-10,20)$ & $-0.0401^{* * *}$ & $-0.0443^{* * *}$ \\
& $(0.0048)$ & $(0.0042)$ \\
\hline
\end{tabular}

Note: $* * *, * *$ and $*$ indicate significant levels of $1 \%, 5 \%$ and $10 \%$ respectively.

In Figure 2, taking 21 days as the event window, we reported the change trend of the CAR of heavily polluting listed companies. The results show that CARs 
of listed companies in heavy polluting industries dropped dramatically and the shock of the start-up day event was more obvious. However, the shocking effect of the feedback event became more and more significant only on the fifth day after the launch of the Central Environmental Inspection. One possible reason is that the feedback is a sequential process. With the mass reporting of the feedback results in various news media, public attention increased quickly which induced investment behaviors to react quickly and lead to the decrease of returns of Listed Companies in heavyly polluting industries. In the whole event window $(-10,10)$, the start and feedback of central environmental inspection made the listed companies in the heavyly polluting industries get - $2 \%$ and - 3\% CARs respectively.

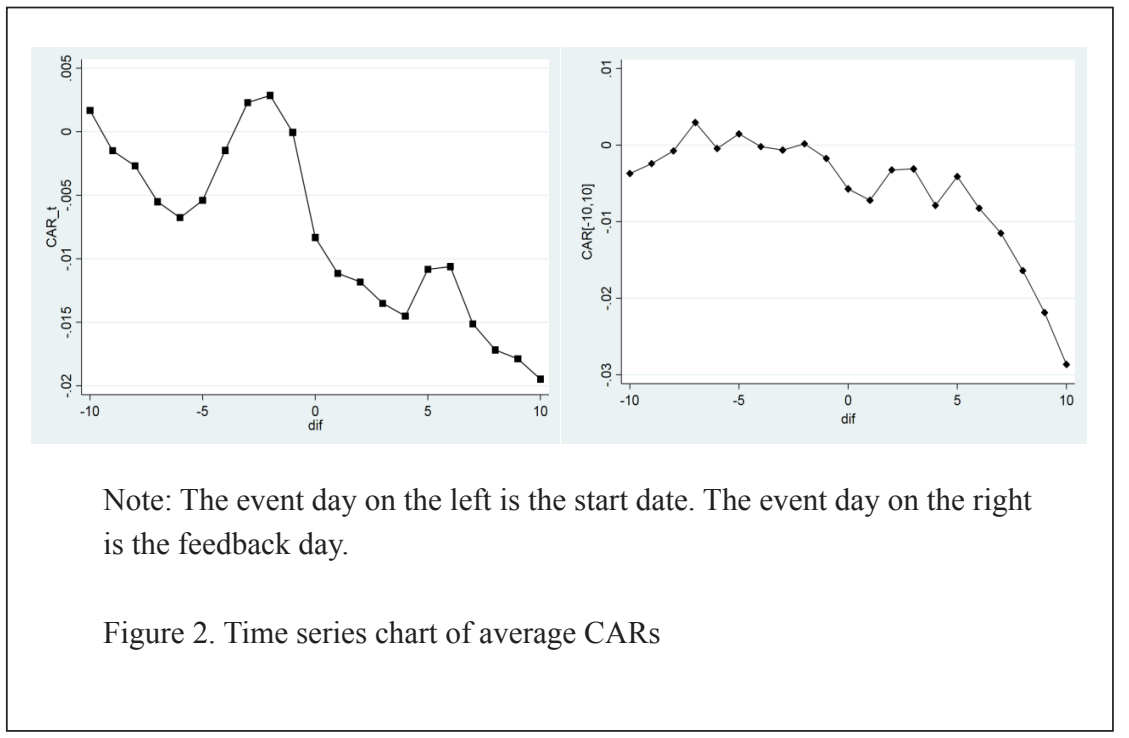

\subsection{Robustness Checks}

The key of the event study is to identify the causal effect of central environmental inspection on the stock market. It is necessary to judge whether the change trend of CARs after event day was really caused by the central environmental inspection. Firstly, we tested whether the CARs day by day before the event day was significant. If the CARs was only significant after the event day, it could be proved that the result above was valid. Secondly, we examined the result again excluding the listed companies that were likely to be affected by other related events in the event window. Specifically, we deleted the sample with more than five days trading interval after the event day and the sample with dividend payment, changes in equity and major trading events happened during the event window. 
In Table 4, we presented the estimated timing results with the sample deleting the listed companies that may be affected by other important events during the event window. Firstly, the shocked effects of start-up event and feedback event are still significantly negative, though the effect has become smaller. As shown in Table 4, the CARs are $-2.3 \%$ and $-2.5 \%$ respectively in the event window $(-10,10)$. We can also find that the CARs are all insignificant within five days before the event date. Thus, our estimated results are not disturbed obviously by other events, such as information disclosed in advance. The result in Table 4 means that the central environmental inspection brings a significant negative market response.

Table 4. Robustness of Market Responses

\begin{tabular}{|c|c|c|c|c|}
\hline \multirow[b]{2}{*}{ Event day } & \multicolumn{2}{|c|}{ Inspection Start } & \multicolumn{2}{|c|}{ Inspection Feedback } \\
\hline & Coefficients & Standard deviation & Coefficients & Standard deviation \\
\hline-10 & $0.0018 *$ & $(0.0009)$ & $-0.0044 * * *$ & $(0.0007)$ \\
\hline-9 & -0.0016 & $(0.0012)$ & $-0.0029 * * *$ & $(0.0010)$ \\
\hline-8 & $-0.0035^{* *}$ & $(0.0015)$ & -0.0013 & $(0.0011)$ \\
\hline-7 & $-0.0064 * * *$ & $(0.0016)$ & $0.0031 * *$ & $(0.0014)$ \\
\hline-6 & $-0.0079 * * *$ & $(0.0019)$ & -0.0008 & $(0.0015)$ \\
\hline-5 & $-0.0067 * * *$ & $(0.0022)$ & -0.0004 & $(0.0017)$ \\
\hline-4 & -0.0027 & $(0.0025)$ & 0.0012 & $(0.0018)$ \\
\hline-3 & 0.0010 & $(0.0027)$ & -0.0013 & $(0.0019)$ \\
\hline-2 & 0.0014 & $(0.0028)$ & 0.0028 & $(0.0022)$ \\
\hline-1 & -0.0024 & $(0.0032)$ & 0.0012 & $(0.0023)$ \\
\hline 0 & $-0.0104 * * *$ & $(0.0034)$ & 0.0019 & $(0.0025)$ \\
\hline 1 & $-0.0140 * * *$ & $(0.0034)$ & -0.0033 & $(0.0025)$ \\
\hline 2 & $-0.0150 * * *$ & $(0.0033)$ & -0.0014 & $(0.0024)$ \\
\hline 3 & $-0.0173 * * *$ & $(0.0034)$ & -0.0033 & $(0.0024)$ \\
\hline 4 & $-0.0185 * * *$ & $(0.0036)$ & $-0.0053 * *$ & $(0.0026)$ \\
\hline 5 & $-0.0144 * * *$ & $(0.0036)$ & -0.0027 & $(0.0027)$ \\
\hline 6 & $-0.0138 * * *$ & $(0.0036)$ & $-0.0065 * *$ & $(0.0029)$ \\
\hline 7 & $-0.0186^{* * *}$ & $(0.0037)$ & $-0.0090 * * *$ & $(0.0030)$ \\
\hline 8 & $-0.0207 * * *$ & $(0.0039)$ & $-0.0144 * * *$ & $(0.0030)$ \\
\hline 9 & $-0.0214 * * *$ & $(0.0041)$ & $-0.0177 * * *$ & $(0.0031)$ \\
\hline 10 & $-0.0231 * * *$ & $(0.0042)$ & $-0.0255^{* * *}$ & $(0.0031)$ \\
\hline $\mathrm{N}$ & \multicolumn{2}{|r|}{618} & \multicolumn{2}{|r|}{741} \\
\hline
\end{tabular}

Note: $* * *, * *$ and $*$ indicate significant levels of $1 \%, 5 \%$ and $10 \%$ respectively. 


\subsection{Responses of Different Industries}

We calculated the average CARs of different industries over the 21 days event window. In Table 5, most of the industries made significant negative reactions to the first batch of central environmental inspection. And more bigger shock effects were observed in coal mining, ferrous metal mining, chemical industry and rubber industry.

Table 5. Responses of Different Heavy Pollution Industries

\begin{tabular}{|c|c|c|c|c|c|}
\hline \multirow[b]{2}{*}{ Code } & \multirow[b]{2}{*}{ Trade name } & \multicolumn{2}{|c|}{ Start-up event } & \multicolumn{2}{|c|}{ Feedback event } \\
\hline & & mean & $\begin{array}{l}\text { standard } \\
\text { deviation }\end{array}$ & mean & $\begin{array}{l}\text { standard } \\
\text { deviation }\end{array}$ \\
\hline B06 & Coal mining and washing & $-0.0229^{* * *}$ & $(0.0005)$ & $-0.0384^{* * *}$ & $(0.0049)$ \\
\hline B07 & Oil and Gas Exploitation & $0.0214^{* * *}$ & $(0.0007)$ & 0.0012 & $(0.0041)$ \\
\hline B08 & $\begin{array}{l}\text { Ferrous Metal Mine } \\
\text { Mining and Processing }\end{array}$ & $-0.0787^{* * *}$ & $(0.0017)$ & $-0.0256^{* * *}$ & $(0.0095)$ \\
\hline B09 & $\begin{array}{l}\text { Non-ferrous Metal Mine } \\
\text { Mining and Processing }\end{array}$ & $0.0370^{* * *}$ & $(0.0012)$ & $0.0241^{* * *}$ & $(0.0038)$ \\
\hline $\mathrm{C} 13$ & $\begin{array}{l}\text { Agricultural and sideline } \\
\text { food processing }\end{array}$ & $-0.0425^{* * *}$ & $(0.0008)$ & $-0.0348^{* * *}$ & $(0.0034)$ \\
\hline $\mathrm{C} 15$ & $\begin{array}{l}\text { Wine, beverage and } \\
\text { refined tea manufacturing }\end{array}$ & $-0.0244^{* * *}$ & $(0.0009)$ & $-0.0605^{* * *}$ & $(0.0020)$ \\
\hline $\mathrm{C} 17$ & Textile & $-0.0541^{* * *}$ & $(0.0009)$ & $-0.0073^{* * *}$ & $(0.0026)$ \\
\hline $\mathrm{C} 19$ & $\begin{array}{l}\text { Leather, Feather and their } \\
\text { Products and shoemaking }\end{array}$ & $-0.0251^{* * *}$ & $(0.0005)$ & 0.0044 & $(0.0079)$ \\
\hline $\mathrm{C} 22$ & Paper and Paper Products & $-0.0054^{* * *}$ & $(0.0010)$ & $-0.0399^{* * *}$ & $(0.0037)$ \\
\hline $\mathrm{C} 25$ & $\begin{array}{c}\text { Petroleum Processing, } \\
\text { Coking and Nuclear Fuel } \\
\text { Processing }\end{array}$ & $-0.0160^{* * *}$ & $(0.0010)$ & $-0.0215^{* * *}$ & $(0.0044)$ \\
\hline $\mathrm{C} 26$ & $\begin{array}{l}\text { Chemical Materials and } \\
\text { Chemicals }\end{array}$ & $-0.0565^{* * *}$ & $(0.0004)$ & $-0.0316^{* * *}$ & $(0.0015)$ \\
\hline $\mathrm{C} 27$ & $\begin{array}{l}\text { Pharmaceutical } \\
\text { Manufacturing }\end{array}$ & $0.0092^{* * *}$ & $(0.0003)$ & $-0.0408^{* * *}$ & $(0.0012)$ \\
\hline $\mathrm{C} 28$ & $\begin{array}{l}\text { Chemical Fiber } \\
\text { Manufacturing Industry }\end{array}$ & $-0.0135^{* * *}$ & $(0.0010)$ & 0.0041 & $(0.0035)$ \\
\hline $\mathrm{C} 29$ & $\begin{array}{l}\text { Rubber and Plastic } \\
\text { Products }\end{array}$ & $-0.0712^{* * *}$ & $(0.0007)$ & $-0.0283^{* * *}$ & $(0.0032)$ \\
\hline $\mathrm{C} 30$ & $\begin{array}{l}\text { Non-metallic Mineral } \\
\text { Products }\end{array}$ & $-0.0051^{* * *}$ & $(0.0005)$ & $-0.0064^{* *}$ & $(0.0029)$ \\
\hline $\mathrm{C} 31$ & $\begin{array}{l}\text { Ferrous Metal Smelting } \\
\text { and Calendering }\end{array}$ & $-0.0085^{* * *}$ & $(0.0007)$ & $0.0356^{* * *}$ & $(0.0031)$ \\
\hline $\mathrm{C} 32$ & $\begin{array}{c}\text { Nonferrous Metal } \\
\text { Smelting and Calendering }\end{array}$ & $-0.0412^{* * *}$ & $(0.0006)$ & $-0.0258^{* * *}$ & $(0.0035)$ \\
\hline D44 & $\begin{array}{l}\text { Electricity, Thermal } \\
\text { Production and Supply }\end{array}$ & $-0.0030^{* * *}$ & $(0.0004)$ & $-0.0228^{* * *}$ & $(0.0016)$ \\
\hline
\end{tabular}

Note: $* * *, * *$ and $*$ indicate significant levels of $1 \%, 5 \%$ and $10 \%$ respectively. 


\section{Firm Heterogeneity}

In order to investigate the heterogeneous impact of central environmental inspection on the market value of heavily polluted listed enterprises, we selected enterprise ownership, political connection and enterprise scale totally three comparable variables and tested the different shock effects.

\subsection{Ownership}

Table 6 shows that the central environmental inspection has a significant negative impact on the market value of private companies in different event windows. However, the start-up and the feedback event of the supervision both have no significant impact on state-owned enterprises in the 11 days and 21 days event window. Only in the 31 days event window, the negative impact starts to be obvious. Through comparing the results between state-owned and private companies, the negative impact of central environmental inspection on private companies is significantly higher than that of state-owned companies, with significant difference of 2.81 percent. On the one hand, the environmental performance of state-owned listed companies, such as environmental information disclosure, is relatively better than private companies. The study by Cheng et al. (2017) showed that the corporate political connection can influence companies to more actively disclose environmental information but it can also mask political rent-seeking in the guise of protecting the environment. On the other hand, the ability for the state-owned companies to withstand policy risks is higher than that of the private companies which will bring different anticipation to the investors.

Table 6. Different Ownership Companies

\begin{tabular}{ccccccc}
\hline & \multicolumn{3}{c}{ Start-up Event } & \multicolumn{3}{c}{ Feedback Event } \\
& {$[-5,5]$} & {$[-10,10]$} & {$[-10,20]$} & {$[-5,5]$} & {$[-10,10]$} & {$[-10,20]$} \\
\hline Private & $-0.0098^{* * *}$ & $-0.0338^{* * *}$ & $-0.0543^{* * *}$ & $-0.0073^{* *}$ & $-0.0306^{* * *}$ & $-0.0571^{* * *}$ \\
companies & $(-2.93)$ & $(-5.80)$ & $(-8.21)$ & $(-2.10)$ & $(-7.07)$ & $(-10.24)$ \\
State-owned & 0.0054 & -0.0080 & $-0.0192^{* * *}$ & -0.0011 & $-0.0152^{* * *}$ & $-0.0291^{* * *}$ \\
companies & & & & & & \\
& $(1.52)$ & $(-1.38)$ & $(-2.82)$ & $(-0.29)$ & $(-3.17)$ & $(-4.71)$ \\
Difference & $-0.0152^{* * *}$ & $-0.0258^{* * *}$ & $-0.0351^{* * *}$ & -0.0062 & $-0.0153^{* *}$ & $-0.0281^{* * *}$ \\
& $(-3.05)$ & $(-3.05)$ & $(-3.61)$ & $(-1.19)$ & $(-2.34)$ & $(-3.33)$ \\
\hline
\end{tabular}

Note: Double-tailed test and $\mathrm{t}$-value in parentheses are shown in the table. $* * *, * *$ and $*$ indicate significant levels of 1 percent, 5 percent and 10 percent respectively under $t$ test. 


\subsection{Political Connections}

Table 7 shows that environmental supervision has a significant negative impact on companies with and without political connection. That means that political affiliation is no longer the main factor affecting the environmental behaviours of polluting companies under the deterrence of central environmental inspection. Even though the impact of central environmental inspection on political affiliated companies is relatively higher, the difference is not so obvious between the companies with and that without the political connections. The results are to a great extent related to the ousting of some local officials brought by the Central Environmental Inspection. Just as the study conducted by Wang et al. (2018), in general, corporate investment expenditures of listed firms decline significantly after the ouster of the politicians, especially for non-SOEs relative to SOEs.

Table 7. Companies with and without Political Connections

\begin{tabular}{ccccccc}
\hline & \multicolumn{3}{c}{ Start-up Event } & \multicolumn{3}{c}{ Feedback Event } \\
& {$[-5,5]$} & {$[-10,10]$} & {$[-10,20]$} & {$[-5,5]$} & {$[-10,10]$} & {$[-10,20]$} \\
\hline With political & -0.0031 & $-0.0190^{* * *}$ & $-0.0352^{* * *}$ & -0.0021 & $-0.0218^{* * *}$ & $-0.0425^{* * *}$ \\
connections & $(-1.06)$ & $(-4.10)$ & $(-6.31)$ & $(-0.66)$ & $(-5.53)$ & $(-8.53)$ \\
$\begin{array}{c}\text { Without political } \\
\text { connections }\end{array}$ & -0.0048 & $-0.0347^{* * *}$ & $-0.0518^{* * *}$ & $-0.0112^{* *}$ & $-0.0301^{* * *}$ & $-0.0532^{* * *}$ \\
& $(-1.02)$ & $(-3.79)$ & $(-5.40)$ & $(-2.64)$ & $(-5.42)$ & $(-6.95)$ \\
Difference & 0.0017 & $0.0156^{*}$ & 0.0166 & 0.0091 & 0.0082 & 0.0107 \\
& $(0.32)$ & $(1.67)$ & $(1.55)$ & $(1.60)$ & $(1.16)$ & $(1.17)$ \\
\hline
\end{tabular}

Note: Double-tailed test and t-value in parentheses are shown in the table. ***,** and * indicate significant levels of $1 \%, 5 \%$ and $10 \%$ respectively under $\mathrm{t}$ test.

\subsection{Firm Size}

According to the total assets, companies are divided into large-scale and small-scale groups. Specifically, companies below the median are identified as small-scale companies and those above the median are identified as large-scale companies. By comparison, the impact of central environmental inspection on the market value of small-scale companies is significantly greater than that of large-scale companies. As shown in table 8, the impact of the startup and the feedback event on the market value of large-scale companies is 6 and 5 percentage points smaller than that of the small-scale companies in the event window of 31 days. Many studies have proved that environmental regulation brought a more adverse effect on small-scale enterprises, such as large firms can successfully lobby government and are less likely to exit a heavily regulated industry than small firms. 
Table 8. Companies with Different Scales

\begin{tabular}{ccccccc}
\hline & \multicolumn{3}{c}{ Start-up Event } & \multicolumn{3}{c}{ Feedback Event } \\
& {$[-5,5]$} & {$[-10,10]$} & {$[-10,20]$} & {$[-5,5]$} & {$[-10,10]$} & {$[-10,20]$} \\
\hline \multirow{2}{*}{ Small-scale } & $-0.0138^{* * *}$ & $-0.0353^{* * *}$ & $-0.0691^{* * *}$ & $-0.0094^{* *}$ & $-0.03357^{* * *}$ & $-0.0693^{* * *}$ \\
& $(-3.84)$ & $(-5.67)$ & $(-9.67)$ & $(-2.54)$ & $(6.99)$ & $(-12.69)$ \\
Large-scale & $0.0071^{* *}$ & $-0.0095^{*}$ & -0.0094 & 0.0003 & $-0.01547^{* * *}$ & $-0.0195^{* * *}$ \\
& $(2.16)$ & $(-1.75)$ & $(-1.53)$ & $(0.08)$ & $(-3.55)$ & $(-3.19)$ \\
Difference & $-0.0035^{* * *}$ & $-0.0234^{* * *}$ & $-0.0597^{* * *}$ & $-0.0097^{*}$ & $-0.01817^{* * *}$ & $-0.0498^{* * *}$ \\
& $(-4.28)$ & $(-3.08)$ & $(-6.32)$ & $(-1.88)$ & $(-2.79)$ & $(-6.10)$ \\
\hline
\end{tabular}

Note: Double-tailed test and t-value in parentheses are shown in the table. $* * *, * *$ and * indicate significant levels of 1 percent, 5 percent and 10 percent respectively under $t$ test.

\subsection{Inspected and Non-inspected Provinces}

According to target provinces of the first batch of central environmental inspection, we divided the research sample into inspected and non-inspected provinces. The result shows that although the start and the feedback event of the central environmental inspection both exert a significant negative impact on the companies in inspected and non-inspected provinces, there is no significant difference between the two categories which illustrates that the supervision has a diffusive impact on other provinces (Table 9).

Table 9. Inspected and Non-Inspected Provinces

\begin{tabular}{ccccccc}
\hline & \multicolumn{3}{c}{ Start-up Event } & \multicolumn{3}{c}{ Feedback Event } \\
\cline { 2 - 7 } & {$[-5,5]$} & {$[-10,10]$} & {$[-10,20]$} & {$[-5,5]$} & {$[-10,10]$} & {$[-10,20]$} \\
\hline Inspected & -0.0063 & $-0.0236^{* * *}$ & $-0.0443^{* * *}$ & 0.0023 & $-0.0139^{*}$ & $-0.0414^{* * *}$ \\
provinces & $(0.0049)$ & $(0.0081)$ & $(0.0104)$ & $(0.0053)$ & $(0.0071)$ & $(0.0082)$ \\
$\begin{array}{c}\text { Non-inspected } \\
\text { provinces }\end{array}$ & -0.0028 & $-0.0183^{* * *}$ & $-0.0389^{* * *}$ & $-0.0068^{* *}$ & $-0.0271^{* * *}$ & $-0.0451^{* * *}$ \\
& & & & & & \\
\multirow{2}{*}{ Difference } & $0.0028)$ & $(0.0044)$ & $(0.0054)$ & $(0.0029)$ & $(0.0036)$ & $(0.0048)$ \\
& $(0.0059)$ & $(0.0092)$ & $(0.0115)$ & $(0.0062)$ & $(0.0077)$ & $(0.0100)$ \\
\hline
\end{tabular}

Note: Double-tailed test and t-value in parentheses are shown in the table. $* * *, * *$ and $*$ indicate significant levels of $1 \%, 5 \%$ and $10 \%$ respectively under $t$ test. 


\section{Conclusion}

By analysing the first batch of central environmental inspection in China, we estimated the short-term effect of policy events on the market value of heavypolluted listed companies. And to further demonstrate the heterogeneous micro effect of central environmental inspection, we investigated the group of listed companies that was more sensitive to the policy shocks. The results show that the central environmental inspection has a significant negative impact on listed companies in heavy polluting industries and the impact is more obvious in coal mining, ferrous metal mining, chemical, rubber and other industries. That is, the environmental supervision can urge the listed companies to improve environmental behaviours effectively to avoid the negative effect on the stock market. In addition, the central environmental inspection has been found to have a more significant negative effect on the market value of private companies and small-scale companies. At the same time, the implementation of central environmental inspection broken the political linkages between polluting enterprises and local governmentand aslo caused a nationwide diffusion effect. The results of this study confirm the real effect of central environmental inspection. Firstly, the event has a significant negative impact on the market value of heavily polluted listed companies. The environmental policy signals are transmitted to the investors effectively through the implemention of central environmental inspection which can guide many investors to pay more attention to the environmental performance of listed companies and promote heavily polluted companies to concern about its own environmental performance in the stock market. Secondly, the central environmental inspection breaks the role of political links in local environmental pollution and causes deterrent effect to some local governments that have shielded the polluting enterprises, weakening the partial behaviour of local governments and promoting the implementation of environmental policies. This output provides some empirical evidence to support the practical effect of the central environmental supervision and provide new evidence to verify the relationship between environmental supervision and market value. Our research also has some limitations. For example, we only recognise the short-term impact of policy shocks on the market value of listed companies and cannot judge the long-term effect of environmental policies on corporate environmental management well. In addition, due to the limitations of the research sample, we cannot effectively see the impact of environmental policies on SMEs. These questions need to be further explored in future.

\section{Acknowledgments}

The authors are grateful for the financial support of The National Social Science Foundation of China (Project No. 19CJY029). 


\section{References}

Badrinath, S. G., \& Bolster, P. J. (1996). The role of market forces in EPAepa enforcement activity. Journal of Regulatory Economics, 10(2), 165-181.

Bailey, J. B., \& Thomas, D. W. (2017). Regulating away competition: Tthe effect of regulation on entrepreneurship and employment. Journal of Regulatory Economics, 52(3), 237-254.

Becker, R. A. (2011). Local environmental regulation and plant-level productivity. Ecological Economics, 70(12), 2516-2522.

Bina, O. (2010). Environmental governance in Cchina: Wweakness and potential from an environmental policy integration perspective. China Review, 10(1), 207-239.

Cheng Z., Wang F., Keung C., \& Bai, Y. (2017). Will corporate political connection influence the environmental information disclosure level? Based on the panel data of A-shares from listed companies in Sshanghai stock market. Journal of Business Ethics, 143(1): , 209-221.

China ecological environment status bulletin. Retrieved May 20, 2019, from Ministry of Environmental Protection of the People's Republic of China. (2018). China ecological environment status bulletin 2017.

China Reviews 1st Round of Central Environmental Protection Supervision. Retrieved May 20, 2019, from Available online: https://chemlinked.com/ news/chemical-news/china-reviews-1st-round-central- environmentalprotection-supervision (accessed on 20 May 2019).

Fang Y., \& Guo J. (2018). Is the environmental violation disclosure policy effective in China: Evidence from capital market reactions. Economic Research Journal, 53(10), 158-174.

Jérôme Foulon J., Lanoie, P., \& Laplante, B. (2002). Incentives for pollution control: Regulation or information? Journal of Environmental Economics and Management, 44(1), 169-187.

Gupta, S., \& Goldar, B. (2005). Do stock markets penalize environmentunfriendly behaviour: Evidence from India. Ecological Economics, 52(1), 81-95.

Helland, E., \& Matsuno, M. (2003). Pollution abatement as a barrier to entry. Journal of Regulatory Economics, 24(2), 243-259.Available online: http://www.mee.gov.cn/gkml/sthjbgw/qt/201805/t20180531_442212. htm (accessed on 20 May 2019).

Jaffe, A. B., Peterson, S. R., \& Stavins, P. R. N. (1995). Environmental regulation and the competitiveness of U.S. manufacturing: Wwhat does the evidence tell us? Journal of Economic Literature, 33(1), 132-163.

Konar, S., \& Cohen, M. A. (1997). Information as regulation: Tthe effect of community right to know laws on toxic emissions. Journal of Environmental Economics and Management, 32(1), 109-124. 
Lanoie, P., Ambec, S., Cohen, M. A., \& Elgie, S. (2013). The porter hypothesis at 20: Can environmental regulation enhance innovation and competitiveness?. Review of Environmental Economics and Policy, 7(1), 2-22.

Li, Q., \& Feng, B. (2015). Environmental regulation, political connection and the quality of environmental disclosure: Empirical evidence based on the heavy pollution of listing corporation. Economy and Management, 29(04), 58-66.

Liming, Z., Fei, Y., Li, Y., \& Guichuan, Z. (2019). Impact of political connections on corporate environmental performance: From a green development perspective. Sustainability, 11(5), 1317.

Lu, D., Fu, P., \& Yang, D. (2015). Media type, media coverage and internal control quality of listed firms. Accounting Research, 41(4), 78-85.

Lundgren, T., \& Olsson, R. (2010). Environmental incidents and firm valueinternational : Eevidence using a multi-factor event study framework. Applied Financial Economics, 20(16), 1293-1307.

Maung, M., Wilson, C., \& Tang, X. (2016). Political connections and industrial pollution: Eevidence based on state ownership and environmental levies in China. Journal of Business Ethics, 138(4), 649-659.

Miroshnychenko, I., Barontini, R., \& Testa, F. (2017). Green practices and financial performance: A global outlook. Journal of Cleaner Production, 147(3), 340-351.

Poncet, S., Steingress, W., \& Vandenbussche, H. (2016). Financial constraints in Cchina: Firm-level evidence. Social Science Electronic Publishing, 21(3), 411-422.

Qian, A. M., \& Yu, Z. (2017). Government's environmental regulation, officials' promotion pressure and enterprises' technological innovation. Technology Economics, 36(12), 11-22.

Ramiah, V., Martin, B., \& Moosa, I. (2013). How does the stock market react to the announcement of green policies? Journal of Banking and Finance, 37(5), 1747-1758.

Shen, H., Ong-B.O, S., Xie Yue, X., \& Chen, Z, R. (2012). Environmental protection, corporate social responsibility and its market response: Case study based on the environmental pollution incident of Zijin Mining Group. China Industrial Economics, 32(1), 141-151.

Wang, F., Xu, L., Zhang, J., \& Shu, W. (2018). Political connections, internal control and firm value: Evidence from China's anti-corruption campaign. Journal of Business Research, 86(5), 53-67.

WangYao, YW., \& Li, Zheyuan, L. I. Y. (2013). Green-efficiency of stock market in Cchina: Stock markets reaction to 2003-2012 environmental events. Finance and Trade Economics, 41(2), 37-48. 
Xu, X. D., Zeng, S. X., \& Tam, C. M. (2012). Stock market's reaction to disclosure of environmental violations: Eevidence from China. Journal of Business Ethics, 107(2), 227-237.

Zhang, B., Chen, X., „, \& Guo H. (2018). Does central supervision enhance local environmental enforcement? Quasi-experimental evidence from China. Journal of Public Economics, 164(8), 70- 90.

Zhang, Gen, -W.en, Z., \& Wang -FZhang, Wei. , Z., (2017). Profitability, environmental enforcement and the share price response to environmental law-based on the release of "the new environmental protection law. Journal of Guizhou University of Finance and Economics, 25(1), 59-69.

Zhang, L., Ye, F., Yang, L., \& Zhou, G. (2019). Impact of political connections on corporate environmental performance: From a green development perspective. Sustainability, 11(5), 1317.

Zhou, H., \& Yin, H. (2017). Stock market reactions to environmental disclosures: Nnew evidence from China. Applied Economics Letters, 25(1), 1-4. 